\title{
SYSTEMATIC RISK : VARIABEL YANG MEMPENGARUHI
}

\author{
I Nyoman Sujana \\ Jurusan Pendidikan Ekonomi, Fakultas Ekonomi dan Bisnis \\ Universitas Pendidikan Ganesha, Singaraja \\ Singaraja, Indonesia \\ e-mail: sujanatbn@yahoo.com
}

\begin{abstract}
ABSTRAK
Investor dalam mengambil keputusan investasi di pasar modal khususnya saham selalu dihadapkan kepada berbagai risiko. Menurut teori Capital Assets Pricing Model (CAPM), risiko total suatu perusahaan terdiri dari 2(dua) tipe yaitu: risiko sistematis dan risiko tidak sistematis. Dalam artikel ini hanya dibahas risiko sistematis. Risiko sistematis adalah risiko yang berkaitan dengan perubahan yang terjadi di pasar secara keseluruhan. Risiko sistematis ini dipengaruhi oleh kondisi perekonomian, keamanan, politik, dan sebagainya baik yang berasal dari dalam negeri maupun luar negeri. Variabel yang mempengaruhi systematic risk adalah: (1) variabel keuangan yang meliputi: liquidity, financial leverage, operating leverage, profitability, firm size, growth; (2) variabel makro ekonomi yang meliputi: inflasi, suku bunga, market capitalization, dan government deficit.
\end{abstract}

Kata kunci: systematic risk, variabel keuangan, dan variabel makro ekonomi

\section{ABSTRACT}

Investors in making investment decisions in the capital market, especially the stock are always exposed to various risks. According to the theory of Capital Assets Pricing Model (CAPM), the total risk of a company consists of two (2) types: systematic risk and unsystematic risk. Discussed in this article only systematic risk. Systematic risk is the risk associated with changes in the overall market. Systematic risk is influenced by economic conditions, security, political and so good that comes from within the country and abroad. Variables affecting the systematic risk are: (1) The financial variables include: liquidity, financial leverage, operating leverage, profitability, firm size, growth; (2) The macro-economic variables that include: inflation, interest rates, market capitalization, and the government deficit.

Keywords: systematic risk, financial variables and macroeconomic variables.

\section{PENDAHULUAN}

Investor dalam mengambil
setiap keputusan investasi selalu berusaha untuk meminimalisir berbagai risiko yang timbul, baik risiko jangka pendek maupun risiko yang bersifat jangka panjang. Setiap perubahan berbagai kondisi mikro dan makro ekonomi akan turut mendorong terbentuknya berbagai kondisi yang mengharuskan seorang investor memutuskan apa yang harus dilakukan dan strategi apa yang diterapkan agar tetap memperoleh return yang diharapkan.

$\begin{array}{llc}\text { Risiko } & \text { menggambarkan suatu } \\ \text { kegagalan } & \text { perusahaan } & \text { yang } \\ \text { mengakibatkan } & \text { kerugian yang } & \text { tidak } \\ \text { terduga yang akan dialami } & \text { oleh }\end{array}$

perusahaan. Risiko merupakan kemungkinan dari sebuah masalah keuangan yang mempengaruhi kinerja operasi perusahaan atau posisi keuangan, seperti risiko ekonomi, ketidakpastian politik, dan masalah industri. Menurut teori Capital Asset Pricing Model (CAPM) risiko total suatu perusahaan terdiri dari 2 (dua) tipe yaitu risiko sistematis dan risiko tidak sistematis (Lintner, 1965; Sharpe, 1963, 1964).

Risiko sistematis adalah risiko yang berkaitan dengan perubahan yang terjadi di pasar secara keseluruhan. Risiko sistematis ini dipengaruhi oleh kondisi perekonomian, keamanan, politik dan sebagainya baik yang 
berasal dari dalam negeri maupun luar negeri. Perubahan pasar tersebut akan mempengaruhi variabilitas return suatu investasi. Dalam keuangan, risiko sistematis adalah risiko surat-surat berharga yang tidak bisa dikurangi melalui diversifikasi (Brealey \& Meyers, 2000).

Risiko tidak sistematis yaitu risiko yang hanya membawa dampak pada perusahaan yang terkait saja. Risiko tidak sistematis disebabkan oleh inefisiensi manajerial, perubahan teknologi dalam proses produksi, ketersediaan bahan mentah, dan perubahan preferensi konsumen.

$$
\text { Penggunaan }
$$

utang menimbulkan biaya dalam bentuk risiko ekstra (risiko financial) bagi para pemegang saham. Pada tingkat risiko utang yang tinggi, perusahaan mungkin terbentur pada keengganan pihak kreditor untuk memberikan tambahan utang. Hal ini akan menaikkan biaya utang baru yang mungkin akan lebih tinggi dari keuntungan pajak dari utang dan selanjutnya akan menjadi beban para pemegang saham.

Leverage operasi dapat didefinisikan sebagai timbulnya biaya tetap dalam operasi perusahaan yang dikaitkan dengan penggunaan aktiva tetap. Leverage operasi terjadi pada saat perusahaan menggunakan aktiva tetap dalam operasinya (Weston dan Brigham, 1991). Disamping itu pula, perusahaan dengan leverage operasi yang tinggi cenderung berhati-hati dalam menggunakan utang untuk pendanaan, karena utang akan menambah beban tetap bagi perusahaan berupa beban bunga pinjaman.

Leverage keuangan berkaitan dengan sumber dana yang berasal dari utang yang akan mengakibatkan beban tetap tertentu dengan harapan akan meningkatkan keuntungan pemilik modal (Weston dan Brigham, 1991). Meskipun menimbulkan beban tetap, perusahaan lebih memilih utang untuk dijadikan sumber pendanaan perusahaan karena biaya transaksi penerbitan lebih rendah dari pada biaya transaksi penerbitan saham. Ketika leverage keuangan tinggi, maka financial risk perusahaan dan systematic risk juga tinggi.

Firm size merupakan ukuran atau besarnya assets yang dimiliki perusahaan dan mempengaruhi jumlah dana yang dibutuhkan. Perusahaan yang lebih besar lebih mudah mengakses pasar modal. Kemudahan untuk mengakses pasar modal berarti perusahaan memiliki fleksibilitas dan kemampuan untuk mendapatkan dana. Perusahaan yang relatif besar cenderung lebih terdiversifikasi dan tidak mudah mengalami kebangkrutan sehingga risikonya rendah (Titman \& Wessel 1988).

Likuiditas terkait erat dengan arus kas yang merupakan komponen penting dalam perusahaan. Kesulitan likuiditas dapat mengarah pada insolvabilitas yang pada gilirannya menghantarkan perusahaan kepada kebangkrutan. Menurut Jensen (1984), likuiditas berhubungan positif dengan beta karena likuiditas yang tinggi akan menyebabkan moral hazard untuk meningkatkan agency costs dari free cash flow sehingga meningkatkan risiko.

Profitabilitas mencerminkan ukuran kemampuan memperoleh laba (earning power) dari suatu perusahaan untuk mendanai investasi. Profitabilitas suatu perusahaan dapat digunakan untuk meramalkan kemampuan suatu perusahaan memperoleh laba di masa mendatang.

Perusahaan dengan pertumbuhan yang tinggi membutuhkan sumber daya yang berlebih (Cosh \&Hughes, 1994; Roh, 2002) dimana perusahaan membutuhkan pendaanaan untuk melatih sumber daya manusia dan pendidikan. Pertumbuhan berhubungan positif dengan systematic risk (Logue \& Merville, 1972).

Studi empiris yang dilakukan oleh Khaldoun M. Al-Qaisi (2011) yang meneliti hubungan variabel ekonomi makro dengan systematic risk. Hasil temuannya bahwa inflation dan 
government deficit berhubungan positif dengan systematic risk. Sedangkan market capitalization berhubungan negatif dengan systematic risk. Inflasi yang tinggi akan mengubah pengeluaran dalam aktifitas riil (Fama, 1981; dan Geske and Roll, 1983), umumnya berdampak besar terhadap systematic risk. Begitu pula government deficit yang tinggi akan meningkatkan pajak yang mengarah pada peningkatan systematic risk (Dilip K., Patro, 2000). Market capitalization yang tinggi menyebabkan systematic risk yang rendah karena semakin banyak jumlah uang yang dihasilkan oleh sebuah pasar modal, maka beta semakin rendah. Artikel ini akan menyajikan variabel yang mempengaruhi systematic risk yang meliputi: variabel keuangan dan makro ekonomi.

\section{PEMBAHASAN}

\section{Variabel yang Mempengaruhi Systematic Risk}

Dalam artikel ini ada 2 (dua) faktor yang mempengaruhi systematic risk yaitu: variabel keuangan dan variabel makroekonomi. Variabel keuangan terdiri dari: liquidity, financial leverage, operating leverage, profitability, firm size, dan growth. Sedangkan variabel makro ekonomi terdiri dari: inflasi, suku bunga, market capitalization, dan government dificit.

\subsection{Variabel Keuangan}

\section{a. Liquidity dan Systematic Risk}

Likuiditas adalah kemampuan suatu perusahaan untuk membayar kewajiban-kewajiban yang harus segera dipenuhi. Likuiditas terkait erat dengan arus kas yang merupakan komponen penting dalam perusahaan. Kesulitan likuiditas dapat mengarah kepada insolvabilitas yang pada gilirannya menghantarkan perusahaan kepada kebangkrutan. Likuiditas sangat menunjang kelancaran usaha, menjamin perusahaan beroperasi dengan baik, mampu membayar kebutuhan jangka pendek, membayar operasional perusahaan dan sebagainya.
Beberapa studi empiris yang dilakukan oleh Beaver et al.,(1970); Logue \& Merville (1972); Moyer \& Chartfield (1983) menyatakan bahwa likuiditas berhubungan negatif dengan systematic risk dimana perusahaan dengan likuiditas yang besar mempunyai systematic risk yang rendah. Namun menurut Jensen (1984), likuiditas berhubungan positif dengan beta karena likuiditas yang tinggi akan menyebabkan moral hazard untuk meningkatkan agency cost dari cash flow dan meningkatkan risiko.

\section{b. Financial Leverage dan Systematic Risk}

Financial leverage berkaitan dengan sumber dana yang berasal dari utang yang akan mengakibatkan beban tetap tertentu dengan harapan akan meningkatkan keuntungan pemilik modal (Weston dan Brigham, 1991). Meskipun menimbulkan beban tetap, perusahaan lebih memilih utang untuk dijadikan sumber pendanaan perusahaan karena biaya transaksi penerbitan lebih rendah daripada biaya transaksi penerbitan saham.

Beberapa studi empiris dilakukan oleh Amit \& Livnat (1988); Borde (1998); Bowman, 1979); Kim et al.,(2002); Modigliani \& Miller (1958); Moyer \& Chartfield (1983) menyatakan bahwa financial leverage berhubungan positif dengan systematic risk, sedangkan menurut Richard A. Lord (1996) pengaruhnya negatif.

\section{c. Operating Leverage dan Systematic Risk}

Operating Leverage dapat didefinisikan sebagai timbulnya biaya tetap dalam operasi perusahaan yang dikaitkan dengan penggunaan aktiva tetap. Operating leverage terjadi pada saat perusahaan menggunakan aktiva tetap dalam operasinya (Weston dan Brigham, 1991). Beberapa studi yang dilakukan oleh Borde (1998); Gu \& Kim (2002); Logue \&Merville (1972) menyatakan bahwa operating leverage berhubungan negatif dengan systematic 
risk. Sedangkan menurut Mandelker (1984) hubungannya positif.

\section{d. Profitability dan Systematic Risk}

Profitability mencerminkan ukuran kemampuan memperoleh laba (earning power) dari suatu perusahaan untuk mendanai investasi. Earning power dari suatu perusahaan merupakan basic concern dari para pemegang saham. Profitability suatu perusahaan dapat digunakan untuk meramalkan kemampuan perusahaan memperoleh laba di masa mendatang. Beberapa studi empiris yang dilakukan oleh Borde (1998); Gu \& Kim (2002); Logue \& Merville (1972) Scherrer \& Mathison (1996) menyatakan bahwa profitability berhubungan negatif dengan systematic risk, dimana profitability yang tinggi menunjukkan ketidakstabilan keuangan yang rendah dan systematic risk yang kecil. Sedangkan menurut Borde, Chambliss, \& Madura (1994) hubungannya positif.

\section{e. Firm Size dan Systematic Risk}

Firm size merupakan ukuran atau besarnya assets yang dimiliki perusahaan. Perusahaan yang lebih besar lebih mudah mengakses pasar modal. Kemudahan untuk mengakses pasar modal berarti perusahaan memiliki fleksibilitas dan kemampuan untuk mendapatkan dana. Beberapa studi empiris tentang hubungan firm size dengan systematic risk telah dilakukan oleh Ben-Zion \& Shalit (1975); Breen \& Lerner (1973); Gu \& Kim (2002);Kim et al., (2002); Logue \& Merville (1972; Melicher (1974). Perusahaan yang relatif besar cenderung terdiversifikasi dan tidak mudah mengalami kebangkrutan sertata risikonya rendah (Titman \& Wessels, 1988). Sekuritas perusahaan yang besar merupakan asset yang mudah dipasarkan sehingga mudah diubah dalam bentuk kas sehingga risikonya kecil (Fisher, 1959). Dengan alasan tersebut, maka firm size berhubungan negatif dengan systematic risk. Sedangkan menurut Melicher
(1974) bahwa hubungan firm size dengan systematic risk adalah positif.

\section{f. Growth dan Systematic Risk}

Pertumbuhan perusahaan sering diukur dengan pertumbuhan asset dan pendapatan, umumnya mengarah pada perubahan ekonomi (Logue \& Merville, 1972). Perusahaan dengan pertumbuhan tinggi membutuhkan sumber daya yang berlebih ( Cosh \&Hughes, 1994; Roh, 2002), yang menyebabkan

perusahaan membutuhkan pendanaan untuk pelatihan sumber daya manusianya dan pendidikan. Oleh karena itu, pertumbuhan perusahaan berhubungan positif dengan systematic risk. Sedangkan menurut Borde (1998) bahwa hubungannya negatif.

\subsection{Variabel Makro Ekonomi \\ a. Inflasi dan Systematic Risk}

Inflasi merupakan salah satu indikator ekonomi makro yang mempengaruhi perekonomian suatu negara. Laju inflasi merupakan laju perubahan harga secara umum (Samuelson, 2010). Laju inflasi dihitung dengan menggunakan tingkat harga dengan menyusun indeks harga. Tingkat harga merupakan rata-rata tertimbang harga dari barang dan jasa yang berbeda di dalam suatu perekonomian. Suatu indeks merupakan rata-rata tertimbang harga dari sejumlah barang dan jasa. Tingginya laju inflasi menggambarkan ketidakstabilan dan kegagalan pengendalian kebijakan makroekonomi suatu negara yang dapat mengakibatkan turunnya daya beli (purchasing power), naiknya biaya modal, biaya tenaga kerja, dan biaya bahan baku serta dapat menimbulkan resesi. Jeon (2001) dan Khaldoun M. Al-Qaisi (2011) menyatakan bahwa inflasi berhubungan positif dengan systematic risk. Sedangkan menurut Verma dan Soydemir (2006) hubungannya negatif. 


\section{b. Suku Bunga dan Systematic Risk}

Naik turunnya suku bunga dapat mempengaruhi kegiatan investasi yang dilakukan suatu negara. Indikator suku bunga yang digunakan dalam penelitian ini adalah suku bunga SBI, karena suku bunga SBI paling banyak digunakan sebagai dasar dalam menentukan premi risiko dan salah satu investasi yang bebas risiko. Tingginya tingkat suku bunga SBI menyebabkan ada kecendrungan investor untuk mengalihkan investasi ke deposito yang merupakan salah satu investasi bebas risiko. Jin-Soo Lee dan Soo Cheong (Shawn) Jang (2007) menyatakan bahwa suku bunga berhubungan positif dengan systematic risk. Sedangkan menurut Khaldoun M. Al-Qaisi (2011) bahwa hubungan suku bunga dan systematic risk adalah negatif.

\section{c. Market Capitalization dan Systematic Risk}

\section{Market}

Capitalization merupakan jumlah uang yang dihasilkan oleh sebuah pasar modal. Market capitalization yang semakin tinggi, maka pasar modal memiliki jumlah uang yang berlebih sehingga tidak mudah mengalami kesulitan keuangan. Oleh karena itu, market capitalization yang tinggi maka systematic risknya rendah. Khaldoun M. Al-Qaisi (2011) menyatakan bahwa market capitalization berhubungan negatif dengan systematic risk. Sedangkan menurut Logue \& Merville ( 1972) bahwa market capitalization dan systematic risk hubungannya positif.

\section{d. Government Dificit dan Systematic Risk}

Government dificit merupakan suatu keadaan dimana suatu negara mengalami kekurangan pembiayaan dalam penyelenggaraan pemerintahannya. Salah satu cara yang ditempuh adalah dengan jalan menaikkan pajak, sehingga systematic risknya juga meningkat. Studi empiris yang dilakukan oleh Dilip K. Patro (2000); Khaldoun M. Al-Qaisi (2011) menemukan bahwa government déficit berhubungan positif dengan systematic risk. Sedangkan menurut Mandelbort dan Hudson (2004) mengatakan bahwa hubungannya negatif.

\section{PENUTUP}

Berdasarkan pembahasan di atas, maka dapat disimpulkan sebagai berikut.

Systematic Risk (risiko sistematis) adalah risiko yang berkaitan dengan perubahan yang terjadi di pasar secara keseluruhan dan tidak bisa dikurangi melalui diversifikasi. Risiko sistematis ini dipengaruhi oleh kondisi perekonomian, keamanan, politik, dan sebagainya baik yang berasal dari dalam negeri maupun luar negeri. Variabel yang mempengaruhi Systematic Risk adalah: (1) variabel keuangan yang meliputi: liquidity, financial leverage, operating leverage, profitability, firm size, growth; (2) variabel makro ekonomi yang meliputi: inflasi, suku bunga, market capitalization, dan government dificit.

\section{DAFTAR PUSTAKA}

Borde,S.F. 1988. Risk Diversity Across Restaurants. Cornel Hotel Quarterly and Restaurant Administration Quarterly, 39(6):64-69.

Brealey, R.A., \& Myers, S.C. 2000. Principles of Corporate Finance (6th ed). Burr Ridge, IL: Irwin/McGraw. Hill.

Cosh, A.D., \& Hughes, A. 1994. Size, Financial Structure and Profitability.In A. Hugher, \& D.J. Storey(Eds), Finance and The Small Firm. London: Routledge: 18-63.

Dilip K. Patro, Jhon K. Wald, and Yangru Wu. 2000. The Impact of Macroeconomic and Financial Variables on Market Risk. Social Science Research. 
Kim, H., Gu, Z., \& Mattila, A.S. 2002. Hotel Real Estate Investment Trusts Risk Features and Beta Determinants. Journal of Hospitality \& Tourism Research, 26(2): 138-154.

Lee, Jin-Soo and Soo Cheong (Shawn) Jang. 2007. The Systematic Risk Determinants of the US Airline Industry Tourism Management:434-442.

Lintner, J. 1965. Security Prices, Risk and Maximal Gains from Diversification. Journal of Finance, 20(4): 587-615.

Mandelker, Gershon N., and S. Ghon Rhee. 1984. The Impact of the Degree of Operating and Financial Leverage on Systematic Risk of Common Stock. Journal of Financial and Quantitative Analysis, 19, No. 1: 45-57..
Morelli, D., 2014.Momentum Profits and Conditional Time-Vary Systematic Risk.Journal of International Financial Markets, Institutions \& Money, 29: 242255.

Samuelson, P.A., and Nordhaus, W.D, 2010. Economics.19th Edition, McGraw-Hill International Edition.

Sharpe, W.F. 1964. Capital Assets Prices: A Theory of Market Equilibrium under Conditions of Risk. Journal of Finance, 19(3) : 425-442.

Titman, S. \& Wessels, R. 1988. The Determinants of Capital Structure Choice. Journal of Finance, 35-41.

Weston, J.F., and Brigham, E.F., 1991. Essentials of Managerial Finance. Tenth Edition. The Dryden Press. United State of America. 